\title{
Androstenediol and dehydroepiandrosterone protect mice against lethal bacterial infections and lipopolysaccharide toxicity
}

\author{
DAVID BEN-NATHAN $\ddagger$ DAVID A. PADGETT* and ROGER M. LORIA $\dagger$ \\ Department of Oral Biology, College of Dentistry, Ohio State University, Columbus, OH 43210 and \\ $\dagger$ Department of Microbiology, Immunology and Pathology, Virginia Commonwealth University, Medical College \\ of Virginia, Richmond, VA 23298-0678, USA
}

\begin{abstract}
The protective effects of the hormones androstenediol (androstene-3 $\beta, 17 \beta$,-diol; AED) and

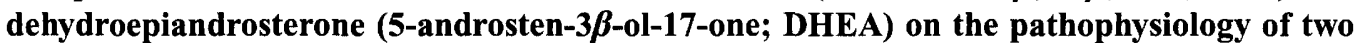
lethal bacterial infections and endotoxin shock were examined. The infections included a gram-positive organism (Enterococcus faecalis) and a gram-negative organism (Pseudomonas aeruginosa). Both hormones protected mice from the lethal bacterial infections and from lipopolysaccharide (LPS) challenge. Treatment of animals lethally infected with $P$. aeruginosa with DHEA resulted in a $43 \%$ protection whereas treatment with AED gave a $67 \%$ protection. Both hormones also protected completely animals infected with an LD50 dose of $E$. faecalis. Similarly, the $88 \%$ mortality rate seen in LPS challenge was reduced to $17 \%$ and $8.5 \%$, by treatment with DHEA and AED, respectively. The protective influences of both steroids were shown not to be directly antibacterial, but primarily an indirect antitoxin reaction. DHEA appears to mediate its protective effect by a mechanism that blocks the toxin-induced production of pathopysiological levels of tumour necrosis factor- $\alpha$ (TNF- $\alpha$ ) and interleukin-1. AED usually had greater protective effects than DHEA; however, the AED effect was independent of TNF- $\alpha$ suppression, both in vivo and in vitro. The data suggest that both DHEA and AED may have a role in the neuro-endocrine regulation of antibacterial immune resistance.
\end{abstract}

\section{Introduction}

Androstenediol (androstene-3 $\beta \quad 17 \beta$-diol; AED) and dehydroepiandrosterone (5-androsten-3 $\beta$-ol-17-one; DHEA) have been shown to exert an influence upon the immune system that results in a generalised and nonspecific increase of host resistance against infections. Several models of acute virus infection have been used to determine the influence of both AED and DHEA on the pathophysiology of infection. The results of these studies have illustrated protection against six different human RNA and DNA viruses including West Nile, Sindbis and Semliki Forest [1-3], coxsackievirus B4, herpes simplex type 2 [4-6] and influenza A virus [7]. These studies led to the conclusion that administration of AED or DHEA up-regulated host immunity and reduced the virulence of

Received 29 May 1998; revised version received 28 July 1998; accepted 14 Aug. 1998.

Corresponding author: Dr R. M. Loria. $\ddagger \mathrm{Dr}$ Ben-Nathan is a visiting professor from the Departments of Infectious Diseases and Biotechnology, The Israel Institute of Biological Research, Ness-Ziona, Israel. both RNA or DNA viruses that are lethal by widely different pathogenic mechanisms [8].

Because of their immunoregulatory influences, it was pertinent to examine the effects of these hormones on two models of lethal bacterial infection. In particular, the aim was to investigate the influence of AED and DHEA on both a gram-positive infection (Enterococcus faecalis) and a gram-negative infection (Pseudomonas aeruginosa). These two organisms are known for their resistance to antibiotics and high incidence of infection in diabetics and cancer patients [9, 10]. Therefore, the development of novel antibacterial strategies may provide new approaches to treating opportunist infections caused by resistant organisms.

Although gram-positive and gram-negative bacteria differ in their structural proteins and respective toxins, certain aspects of the pathophysiology of disease are comparable [10-13]. During the course of gram-negative infections, the release of endotoxin (lipopolysaccharide, LPS) can induce intense pathophysiological alterations $[10,14,15]$. One of the major 
responses to LPS in vivo is the rapid production and secretion of pro-inflammatory cytokines, including tumour necrosis factor- $\alpha$ (TNF- $\alpha$ ) [16-18] and interleukin-1 $\alpha[19,20]$. Although gram-positive bacteria lack endotoxin, other constituents of their cell wall and exotoxins can induce TNF- $\alpha$ and IL- $1 \alpha$ production [21, 22]. The elevated production of these potent proinflammatory cytokines has profound influences on the physiology of the host and is responsible for many of the symptoms associated with bacterial infection, including the characteristic high fever and cachexia. Overactivation of this cytokine network can not only damage tissues of the host but can ultimately lead to death [18]. LPS toxicity can be reduced by administration of potent immunosuppressive glucocorticoids that inhibit the production of TNF and other cytokines if given before LPS challenge $[17,23]$. However, the immunosuppressive influences of glucocorticoids leave the host susceptible to infection by other opportunist agents.

\section{Materials and methods}

\section{Preparation of steroid solutions}

DHEA was obtained from Steraloids, (Wilton, $\mathrm{NH}$, USA). AED was purchased from Sigma [2, 6, 24]. Unless otherwise stated these steroids were dissolved in DMSO:EtOH (1:1) as the vehicle.

\section{Mice}

CD-1 female mice (Charles River, London) were 21 days old upon arrival and were maintained in the animal facility until the age of 4-6 months. ICR outbred male mice (Harland Sprague Dawley, Indianapolis, IN, USA) were 8 weeks old and underwent adaptation for no less than 1 week before being used. Animal facilities are routinely maintained at $24^{\circ} \mathrm{C}$ with water and food ad libitum.

\section{Bacteria}

$P$ aeruginosa. The virulence of the $P$. aeruginosa strain for mice had been determined previously [25]. A bacterial suspension containing $2 \times 10^{9} \mathrm{cfu} / \mathrm{ml}$ was kept frozen at $-70^{\circ} \mathrm{C}$ in $1-\mathrm{ml}$ tubes until use. Mice (6 months old) were inoculated intraperitoneally (i.p.) with $0.2 \mathrm{ml}$ containing $2 \times 10^{7}$ cfu. AED or DHEA was injected subcutaneously (s.c.) $2 \mathrm{~h}$ before bacterial inoculation.

E. faecalis. E. faecalis $\times 1515.0 G 1 \mathrm{RF}$, a plasmidbearing strain, which is virulent for mice was grown on blood agar. This strain was a generous gift from Dr $\mathrm{H}$. Dalton (Medical College of Virginia, Richmond, VA, USA). The number of cfu was determined by spectrophotometry by reference to standards verified by subculture and plate counts. A dose of $1 \times 10^{10} \mathrm{cfu} /$ animal in $0.5 \mathrm{ml}$ of saline was used i.p. for challenge experiments.

\section{LPS challenge}

A lethal dose $(800 \mu \mathrm{g} / \mathrm{mouse})$ of LPS (Lipopolysaccharide W, Escherichia coli O55:B5; Difco Labora- tories, Detroit, MI, USA), was diluted in pyrogen-free saline and injected into CD-1 mice i.p. DHEA $(80 \mathrm{mg})$ was dissolved in $0.8 \mathrm{ml}$ of absolute alcohol and then diluted with inactivated rabbit serum $(10 \%)$ in saline (RSSP) to give a final volume of $16 \mathrm{ml}$. Each mouse received $2 \mathrm{mg}$ [24]. AED (30 mg) was dissolved in $1.2 \mathrm{ml}$ of absolute alcohol and diluted to a final volume of $15 \mathrm{ml}$ with RSSP. Each mouse was given $0.4 \mathrm{mg}$. Control mice were inoculated with the vehicle only at the same times. Mice were observed daily for mortality for 14 days.

\section{TNF- $\alpha$ assay}

To determine TNF- $\alpha$ production, mice were inoculated with LPS $(100 \mu \mathrm{g} / \mathrm{mouse})$ i.p. $20 \mathrm{~min}$ after the s.c. injection of DHEA or AED. Mice were bled $60 \mathrm{~min}$ after LPS treatment. Blood was collected into serum separator tubes (Becton-Dickinson). Serum was separated and frozen at $-70^{\circ} \mathrm{C}$ until further processing.

\section{In-vitro experiments}

The procedure of Kruisbeek [26] was used for the proliferation of spleen cells from three of four BALB/c or $\mathrm{C} 57 \mathrm{BL} / 6 \mathrm{~J}$ mice. Briefly, the mitogens concanavalin A (ConA) and Escherichia coli LPS were diluted in phosphate-buffered saline (PBS) with fetal calf serum $1 \%$ to a concentration of $1.0 \mathrm{mg} / \mathrm{ml}$. The optimal working concentration of ConA was found to be $2.5 \mu \mathrm{g} / \mathrm{ml}$ while that of LPS was $5.0 \mu \mathrm{g} / \mathrm{ml}$. The viability of spleen cells was determined by exclusion of trypan blue $0.4 \%$ after a haemacytometer count had been made. Unfractionated lymphocytes were maintained in RPMI 1640 containing FCS $10 \%, 200 \mu \mathrm{ML}-$ glutamine, $20 \mathrm{mM}$ Hepes, penicillin $2.5 \mathrm{U} / \mathrm{ml}$, streptomycin $2.5 \mu \mathrm{g} / \mathrm{ml}$ and $5.0 \times 10^{-5} \mathrm{M}$ 2-mercaptoethanol. For proliferation studies, $0.1-\mathrm{ml}$ volumes of the mixed cell suspension at a concentration of $5.0 \times 10^{6} \mathrm{cells} / \mathrm{ml}$ were cultured in 96-well tissue culture plates. For cytokine assays, $1.0-\mathrm{ml}$ volumes of this same cell suspension were cultured in 24-well tissue culture plates. For each study unfractionated spleen cells were incubated at $37^{\circ} \mathrm{C}$ in a $\mathrm{CO}_{2} 5 \%$ incubator. Murine macrophages RAW 264.7 (Ig and complement receptor positive), were obtained from the American Type Culture Collection (ATCC).

TNF- $\alpha$ bioactivity in serum was determined with A-9 cells (ATCC, Rockville, MO, USA). Briefly, $3 \times 10^{4}$ A9 cells were seeded in wells of microtitration plates and allowed to adhere overnight. Wells were treated with serial dilutions of the sample serum followed by addition of cycloheximide $25 \mu \mathrm{g} / \mathrm{ml}$. After incubation for $8-10 \mathrm{~h}$, the cells were washed and the number of surviving cells was determined by uptake of neutral red. The mouse T-cell clone D10.G4.1 was used for measurement of soluble IL-1 and was maintained in complete Clicks- 5 medium containing ConA $2.5 \mu \mathrm{g} / \mathrm{ml}$. For a positive control, recombinant murine IL-1 was 
purchased from R\&D, Minneapolis, USA). In addition, representative results obtained from this assay were verified by repeat measurement with an IL-1-specific ELISA obtained from Genzyme (Cambridge, MA., USA).

\section{Statistical analysis}

Data are presented as means and SD and were analysed for significance by analysis of variance (ANOVA) or by Student's $t$ test, as stated.

\section{Results}

The effects of $A E D$ and DHEA on P. aeruginosa infection

The protective effects of AED and DHEA towards a dose of $2 \times 10^{7} \mathrm{cfu}$ of $P$. aeruginosa that causes $100 \%$ mortality in the strain of mouse used [25] is illustrated in Table 1. Experiments 1 and 2 show that DHEA treatment at a dose of $20 \mathrm{mg}, 2 \mathrm{~h}$ before $P$. aeruginosa injection protected $50 \%$ and $38.5 \%$ of the animals, respectively, in two separate experiments.

A combination of the results of both experiments shows that $43 \%$ of the animals treated with DHEA were protected from a lethal $P$. aeruginosa infection. Similarly, $2 \mathrm{mg}$ of AED resulted in $71.5 \%$ and $62.5 \%$ protection in two separate experiments. A combination of the results of both experiments shows that AED protected $67 \%$ of animals infected with a lethal dose of $P$. aeruginosa.

The results show that treatment with either AED or DHEA in vivo significantly $(\mathrm{p}<0.05)$ increased the survival of mice given a lethal dose. Furthermore, AED is more effective than DHEA against $P$. aeruginosa infection as is evident from the level of protection and the use of one-tenth the dose of DHEA.

\section{The effects of AED and DHEA on E. faecalis infection}

To establish that the effects of these hormones were not limited to gram-negative bacterial infections, the effects of both hormones were tested on a lethal challenge with $E$. faecalis. Treatment of mice infected with this bacterium with a single dose of either AED $(8 \mathrm{mg})$ or DHEA $(25 \mathrm{mg}) 2 \mathrm{~h}$ before bacterial challenge protected all animals, whereas $57 \%$ of untreated animals died $(p<0.05)$ (Fig. 1). Thus, these data show that both AED and DHEA have a similar protective effect against a lethal $E$. faecalis infection.

Table 1. Protective effects of DHEA and AED against lethal infection in mice by $P$. aeruginosa

\begin{tabular}{lccc}
\hline & \multicolumn{3}{c}{ Mortality (\%) } \\
\cline { 2 - 4 } Treatment of & Experiment $1(\mathrm{n}=14)$ & Experiment $2(\mathrm{n}=16)$ & Cumulative data $(\mathrm{n}=30)$ \\
\hline Nonected mice & $14(100)$ & $15(94)$ & $29(97)$ \\
DHEA & $7(50)$ & $10(62.5)$ & $17^{*}(57)$ \\
AED & $4(28.5)$ & $6(37.5)$ & $10^{*}(33)$ \\
\hline
\end{tabular}

Six-month-old CD-1 female mice were infected with $2 \times 10^{7}$ cfu of $P$ aeruginosa; DHEA $20 \mathrm{mg}$ or AED $2 \mathrm{mg}$ was injected s.c. $2 \mathrm{~h}$ before bacterial challenge.

${ }^{*} \mathrm{p}<0.01$ compared with control group.

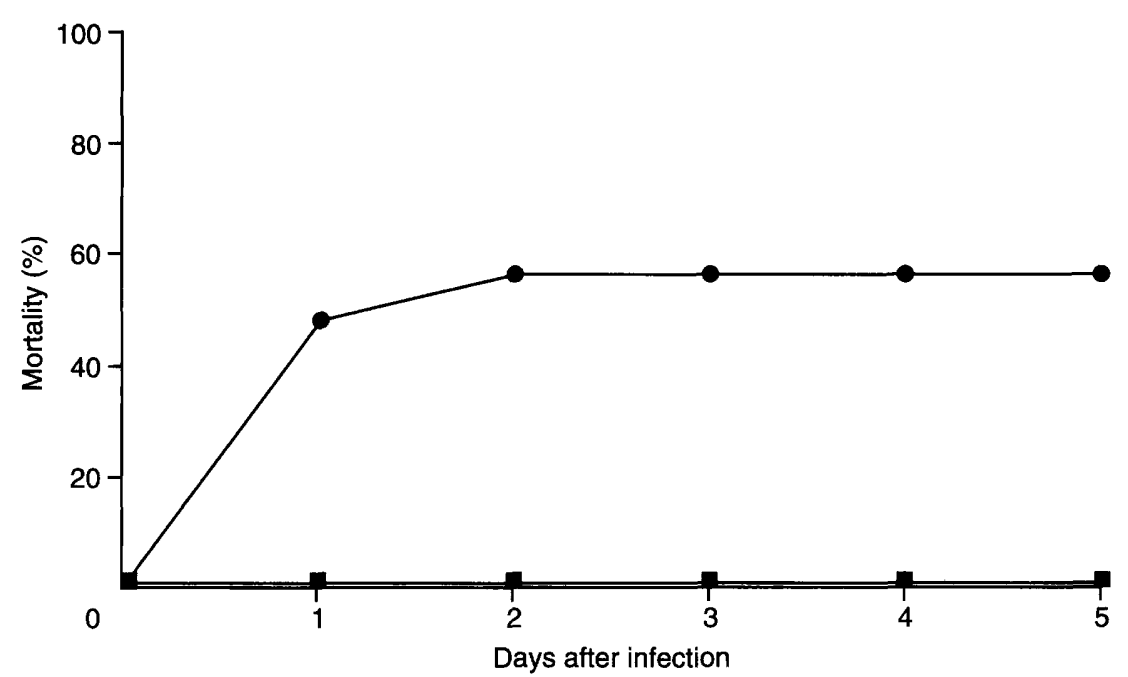

Fig. 1. The protective effects of DHEA and AED against a lethal E. faecalis infection. Mice were inoculated i.p. with $1 \times$ LD50 dose of the organism. Treatment with a single dose of either AED or DHEA ( $25 \mathrm{mg}) 2 \mathrm{~h}$ before bacterial challenge afforded complete protection, whereas $57 \%$ of control animals died $(\mathrm{p}<0.05)$; E. faecalis + AED or DHEA, $\bullet$ E. faecalis only. 
The absence of direct antibacterial effects of AED or DHEA at concentrations ranging from $5 \times 10^{-4} \mathrm{M}$ to $5 \times 10^{-8} \mathrm{M}$ was determined in veal infusion broth cultures $24 \mathrm{~h}$ after inoculation. Changes in growth rate were determined by $\mathrm{OD}_{340}$ measurements. Untreated E. faecalis control cultures had a mean $\mathrm{OD}_{340}$ reading of 0.8565 (SD 0.01), while the averages of all DHEAand AED-treated cultures were 0.8353 (SD 0.02) and 0.834 (SD 0.02) respectively (10 samples were used for each group). Thus, neither AED nor DHEA altered the growth rate of the bacterium at any of the concentrations tested.

Endotoxic challenge and TNF- $\alpha$ levels: protective effects of AED and DHEA

In all, $88 \%$ of untreated animals inoculated with $800 \mu \mathrm{g}$ of LPS per mouse died within $72 \mathrm{~h}$ (Fig. 2). However, pretreatment with DHEA ( $2 \mathrm{mg}$ ) given $1 \mathrm{~h}$ before the LPS reduced mortality from $88 \%$ to $17 \%$. AED treatment $(0.4 \mathrm{mg})$ reduced LPS-induced mortality from $88 \%$ to $8.5 \%$. Even though both drugs were found to be effective in protecting from LPS toxicity, AED at one-fifth the dose of DHEA was again more protective.

Because LPS is known to mediate an increase in TNF- $\alpha$ levels, the study investigated whether the protective effects of AED or DHEA observed were caused by suppression of LPS-mediated TNF- $\alpha$ secretion in vivo was examined. Fig. 3 shows that $100 \mu \mathrm{g}$ of LPS induced high TNF- $\alpha$ levels in vivo, resulting in an increase from a mean of 1028.0 (SD 90) $\mathrm{pg} / \mathrm{ml}$ in control mice to a mean of 7366.7 (SD 645.8) pg/ml. DHEA treatment

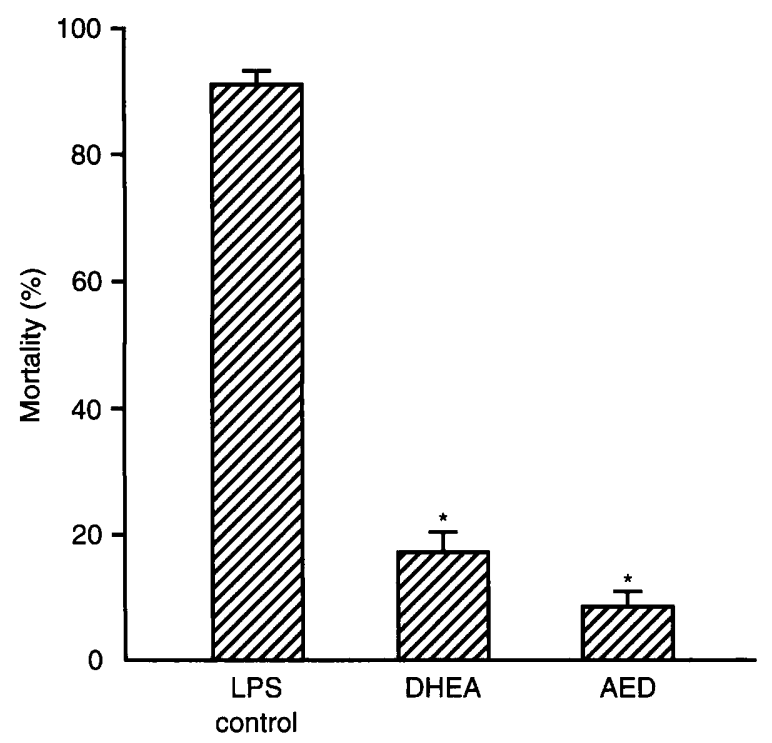

Fig. 2. Protective effects of DHEA and AED against LPS endotoxic shock. CD-1 female mice were each challenged with $800 \mu \mathrm{g}$ of LPS. The steroid, AED $(0.4 \mathrm{mg} / \mathrm{mouse})$ or DHEA ( $2 \mathrm{mg} / \mathrm{mouse})$, was injected s.c. $1 \mathrm{~h}$ before LPS challenge. Each group included 14 animals with 42 animals per experiment. A total of 84 animals was tested. *Statistically significant at $\mathrm{p}<0.01$ by ANOVA.

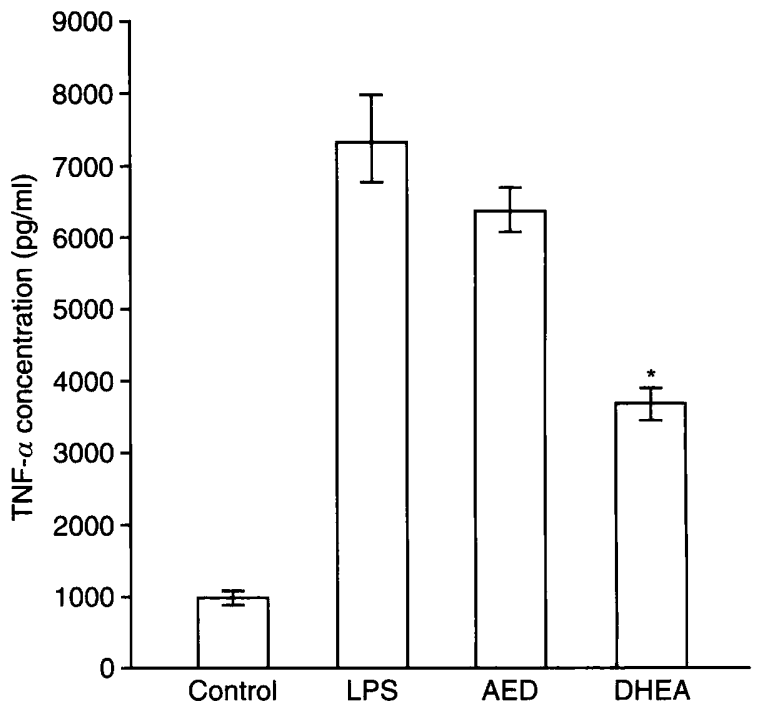

Fig. 3. Effects of DHEA and AED on levels of TNF- $\alpha$ induced in vivo by LPS. Female CD-1 mice (4 months old) were challenged with $100 \mu \mathrm{g}$ of LPS and inoculated i.p. with either AED $(0.4 \mathrm{mg})$ or DHEA $(2 \mathrm{mg})$ in inactivated rabbit serum $10 \%$ in saline containing penicillin, $20 \mathrm{~min}$ before LPS challenge. TNF- $\alpha$ levels were measured $1 \mathrm{~h}$ after LPS challenge. Six animals were used in each test group. ${ }^{*}$ Statistically significant at $\mathrm{p}<0.01$ by ANOVA as compared with the LPS-treated group.

resulted in a marked reduction of TNF- $\alpha$ levels of around $50 \%$. However, the lower dose of AED which protected mice in vivo from lethal challenge, was ineffective in reducing TNF- $\alpha$ levels in this system.

These observations demonstrate that the protective effect of AED and DHEA against bacterial and endotoxin challenge are distinct from each other and that this protective effect of AED is not mediated by the reduction of TNF- $\alpha$.

\section{Influence of $A E D$ and DHEa in vitro}

Because of the ability of DHEA and AED to protect mice against LPS toxicity, the following experiments were designed to examine their roles in vitro. First, the ability of both steroids to modify proliferation of LPSstimulated splenocyte cultures was assessed. C57BL $/ 6$ murine spleen cell cultures stimulated by LPS $5 \mu \mathrm{g} / \mathrm{ml}$ were treated with concentrations of DHEA ranging from $5.0 \times 10^{-6} \mathrm{M}$ to $5.0 \times 10^{-9} \mathrm{M}$. DHEA suppressed proliferation as determined by a reduced $\left[{ }^{3} \mathrm{H}\right]$ thymidine uptake after culture for $24 \mathrm{~h}$ (Table 2), e.g., at $5.0 \times 10^{-6} \mathrm{M}$, DHEA suppressed proliferation by $21.5 \%$ compared with LPS-stimulated controls. In contrast, AED at the same concentrations had no effect on splenocyte proliferation.

Subsequent experiments were designed to determine whether the observed ability of DHEA to suppress TNF- $\alpha$ and IL-1 production in vivo could be modelled in vitro with an LPS-sensitive macrophage cell line. 
Table 2. Effects of DHEA and AED on the proliferation of splenocytes from C57BL/6J mice induced by LPS

\begin{tabular}{lcr}
\hline \multirow{2}{*}{$\begin{array}{l}\text { Concentration } \\
\text { of steroid } \\
(\text { moles } / \mathrm{L})\end{array}$} & \multicolumn{2}{c}{$\begin{array}{c}\text { Mean }(\mathrm{SD})\left[{ }^{3} \mathrm{H}\right] \text { thymidine uptake by } \\
\text { splenocytes exposed to }\end{array}$} \\
\cline { 2 - 3 } $5 \times 10^{-9}$ & DHEA & AED \\
$5 \times 10^{-8}$ & $90.7(3.6)$ & $99.7(3.5)$ \\
$5 \times 10^{-7}$ & $87.0(4.7)$ & $96.7(5.1)$ \\
$5 \times 10^{-6}$ & $83.1(6.5)^{*}$ & $100.3(6.3)$ \\
\hline
\end{tabular}

Splenocytes $(5.0 \times 10$ cells $/ \mathrm{ml})$ were treated with the indicated concentrations of steroid or control vehicle (DMSO $0.2 \%$ : EtOH). Cultures were stimulated with LPS $5.0 \mu \mathrm{g} / \mathrm{ml}$ for $24 \mathrm{~h}$ in 96 -well culture plates and pulsed with $1.0 \mu \mathrm{Ci}\left[{ }^{3} \mathrm{H}\right]$-thymidine for the final $6 \mathrm{~h}$. Data represent six experiments and are expressed as the mean percertage of the control value for each experiment.

${ }^{*}$ Statistically different from control, $\mathrm{p}<0.05$.

Again, treatment of murine macrophages (RAW 264.7) stimulated by LPS $50 \mathrm{ng} / \mathrm{ml}$ with DHEA suppressed the production of both TNF- $\alpha$ and IL-1 (Tables 3 and 4). AED had no effect on the production of either proinflammatory cytokine. These in-vitro measures correlated with those from the in-vivo experiments and further revealed the dichotomy between the function of AED and DHEA even though each steroid hormone protected mice from the lethal effect of bacterial infection and LPS toxicity.

Table 3. Effects of DHEA and AED on the in-vitro production of TNF- $\alpha$ by RAW264.7 murine macrophages stimulated by LPS

\begin{tabular}{lcc}
\hline & \multicolumn{2}{c}{$\begin{array}{c}\text { Mean (SD) TNF- } \alpha(\mathrm{pg} / \mathrm{ml}) \text { secreted by } \\
\text { macrophages exposed to }\end{array}$} \\
\cline { 2 - 3 } $\begin{array}{l}\text { Concentration } \\
\text { (moles } / \mathrm{L} \text { ) }\end{array}$ & DHEA & AED \\
\hline $5 \times 10^{-9}$ & $461.93(27.99)$ & $496.09(38.20)$ \\
$5 \times 10^{-8}$ & $451.53(14.90)$ & $497.58(25.87)$ \\
$5 \times 10^{-7}$ & $451.53(14.90)$ & $521.84(22.96)$ \\
$5 \times 10^{-6}$ & $442.62(19.03)^{*}$ & $490.64(31.89)$ \\
0 (control) & \multicolumn{2}{c}{$495.00(28.6)$} \\
\hline
\end{tabular}

Cultures were stimulated with LPS $50.0 \mathrm{ng} / \mathrm{ml}$ for $24 \mathrm{~h}$. TNF- $\alpha$ was measured with an L929 cytolytic bioassay and confirmed against a standard curve generated with dilutions of recombinant TNF- $\alpha$. Data were compiled from three different experiments $(n=6$ for each determination).

${ }^{*}$ Statistically different from control, $\mathrm{p}<0.05$.

Table 4. Effects of DHEA and AED on the in-vitro production of IL-1 by RAW264.7 murine macrophages stimulated by LPS

\begin{tabular}{|c|c|c|}
\hline \multirow{2}{*}{$\begin{array}{l}\text { Concentration } \\
\text { of steroid } \\
(\text { moles } / \mathrm{L})\end{array}$} & \multicolumn{2}{|c|}{$\begin{array}{c}\text { Mean IL-1 }(\mathrm{pg} / \mathrm{ml}) \text { secreted by macrophages } \\
\text { exposed to }\end{array}$} \\
\hline & DHEA & AED \\
\hline $5 \times 10^{-9}$ & $682.12^{*}$ & 756.13 \\
\hline $5 \times 10^{-8}$ & $688.22^{*}$ & 804.20 \\
\hline $5 \times 10^{-7}$ & $695.85^{*}$ & 766.81 \\
\hline $5 \times 10^{-6}$ & 711.88 & 764.52 \\
\hline 0 (control) & \multicolumn{2}{|c|}{763.00} \\
\hline
\end{tabular}

Cultures were stimulated with LPS $5.00 \mathrm{ng} / \mathrm{ml}$ for $24 \mathrm{~h}$. IL-1 was measured with a bioassay based on a T-cell clone (D10.G41).

${ }^{*}$ Statistically different from control, $p<0.05$.

\section{Discussion}

This study demonstrated the potential of the naturally occurring steroid hormones AED and DHEA to protect against lethal bacterial infections in a rodent model. Both hormones were effective in preventing death from a lethal challenge by either the gram-negative organism $P$. aeruginosa, or the gram-positive $E$. faecalis. Although a precise mechanism of action has not been defined for AED and DHEA, neither steroid appeared to have direct antibacterial effects, because the growth characteristics of $P$. aeruginosa, and E. faecalis were not altered in an in-vitro assay. Furthermore, because both $P$. aeruginosa and $E$. faecalis exert their virulence by their toxigenic actions $[9,10,13]$, the protective effects of these hormones may be mediated, at least in part, by their ability to modulate the actions of virulence factors associated with each organism.

Injection of LPS i.p. has been reported to stimulate the release of many cytokines, including TNF- $\alpha$ and IL-1 $\alpha$, within $45 \mathrm{~min}$. Zuckerman et al. [27] reported that maximal serum TNF- $\alpha$ was detected within $1 \mathrm{~h}$ of injection; elevated levels returned to baseline with 3$4 \mathrm{~h}$. The peripheral inflammatory response elicited as a result of the increase in these cytokines results in activation of a central response involving the hypothalamic-pituitary-adrenal (HPA) axis which among others leads to changes in thermo-regulation, and an overactivation of the immune response [28-30]. Danenberg et al. [24] reported that following inoculation of CD-1 mice with $100 \mu \mathrm{g}$ of LPS, plasma corticosterone levels increased almost eight-fold from $94 \mathrm{ng} / \mathrm{ml}$ to $740 \mathrm{ng} / \mathrm{ml}$. Activation of the HPA axis may function as feedback control over the production of pro-inflammatory cytokines because the principal product of HPA activation, namely adrenal glucocorticoids, suppresses production of TNF- $\alpha$ and IL- $1 \alpha$ by macrophages [31, 32].

This was supported by the observation that the decrease in TNF- $\alpha 3-4 \mathrm{~h}$ after LPS injection correlated with the appearance of significant amounts of endogenous serum corticosterone [27]. Furthermore, treatment of LPS-stimulated mice with the glucocorticoid receptor antagonist RU486 blocked corticosterone function and led to augmented production of serum TNF- $\alpha$ [33]. TNF- $\alpha$ is considered to be a major proximal mediator of septic shock [16, 23, 34-37], a claim substantiated by the finding that passive immunisation against TNF- $\alpha$ protected mice against the lethal effects of LPS [16]. However, TNF is not the sole mediator of LPS-induced phenomena [20], but rather acts in conjunction with other cytokines, augmenting their activity $[27,37]$.

The results reported here support the premise that DHEA protects mice from bacterial infection and LPS toxicity by blocking the toxin-induced production of TNF- $\alpha$ in view of the data showing suppression of 
serum TNF- $\alpha$ levels in vivo and suppression of TNF- $\alpha$ production from cultured macrophages in vitro. The results of this study also show that significantly lower doses of AED had a greater protective effect than DHEA against in-vivo challenge with $P$. aeruginosa, $E$. faecalis or LPS. However, AED did not reduce the levels of TNF- $\alpha$ either in vivo or in vitro. On the basis of these observations, it is apparent that the protective actions of these two hormones operate by different mechanisms, with that if AED being independent of TNF- $\alpha$ production. DHEA has been reported to function as a weak glucocorticoid because it suppressed splenocyte proliferation, T-cell secretion of IL2 and IL-3, [38] and pro-inflammatory monokine production (Tables 3 and 4). Indeed this appears to be similar to the action of glucocorticosteroids after LPS challenge $[24,27,33,39]$. On the other hand, AED did not suppress any of these aspects of immune function. Furthermore, Padgett et al. [7] reported that AED suppressed the activation of the HPA induced by influenza virus. The suppression of corticosterone levels mediated by AED during the influenza infection correlated with increased production of IFN- $\gamma$ from antigen-specific $T$ cells and increased survival. In contrast, Dobbs et al. [40] showed that stress-induced elevation of serum corticosterone during influenza infection suppressed IFN- $\gamma$ production and increased morbidity associated with infection.

Thus the influences of AED clearly differ from those attributed to glucocorticoids and, by inference, to DHEA, because the protective effects of DHEA against bacterial or LPS challenge are mediated in part by its glucocorticoid-like properties which result in suppression of TNF- $\alpha$. However, AED exerted its protective effect by a different as yet unknown mechanism that did not result in suppression of TNF- $\alpha$ production. Further investigations into the possible use of AED in providing protection against antibiotic-resistant opportunist infections may be warranted.

This research was supported in part by a gift to R. M. L. from the SCDR Cancer Research Fund.

\section{References}

1. Ben-Nathan D, Lachmi B, Lustig S, Feuerstein G. Protection of dehydroepiandrosterone in mice infected with viral encephalitis. Arch Virol 1991; 120: 263-271.

2. Ben-Nathan D, Lustig S, Kobiler D, Danenberg HD, Lupu E, Feuerstein G. Dehydroepiandrosterone protects mice inoculated with West Nile virus and exposed to cold stress. J Med Virol 1992; 38: $159-166$

3. Ben-Nathan D, Kobiler D, Feuerstein G, Lustig S. Anti-stress effect of dehydroepiandrosterone (DHEA) on mice inoculated with attenuated arboviruses. Prog Neuroendocrin Immunol 1992; 5: 229-234.

4. Loria RM, Inge TH, Cook SS, Szakal AK, Regelson W. Protection against acute lethal viral infections with the native steroid dehydroepiandrosterone (DHEA). J Med Virol 1988; 26: $301-314$.

5. Loria RM, Padgett DA. Mobilization of cutaneous immunity for systemic protection against infections. Ann NY Acad Sci 1992; 650: 363-366.

6. Loria RM, Padgett DA. Androstenediol regulates systemic resistance against lethal infections in mice. Arch Virol 1992; 127: $103-115$.

7. Padgett DA, Loria RM, Sheridan JF. Endocrine regulation of the immune response to influenza virus infection with a metabolite of DHEA - androstenediol. J Neuroimmunol 1997; 78; $203-211$.

8. Loria RM, Padgett DA, Huynh PN. Regulation of the immune response by dehydroepiandrosterone and its metabolites. $J$ Endocrinol 1996; 150 suppl: S209-S220.

9. Doggett RG. Microbiology of Pseudomonas aeruginosa. In: Doggett RG (ed) Pseudomonas aeruginosa. Clinical manifestations of infection and current therapy. New York, Academic Press, 1979: 1-7.

10. Jawetz E, Melnick J, Adelberg EA. Medical microbiology. East Norwalk, CT. Appleton and Lange. 1995: 132-134, 218-223.

11. Jett BD, Jensen HG, Atkuri RV, Gilmore MS. Evaluation of therapeutic measures for treating endophthalmitis caused by isogenic toxin-production and toxin-nonproducing Enterococcus faecalis strains. Invest Ophthalmol Vis Sci 1995; 36: 9-15.

12. Liu PV. Toxins of Pseudomonas aeruginosa. In: Doggett RG (ed) Pseudomonas aeruginosa. Clinical manifestations of infection and current therapy. New York, Academic Press. 1979: 63-88.

13. Woods DE, Iglewski BH. Toxins of Pseudomonas aeruginosa: new perspectives. Rev Infect Dis 1983; 5 Suppl 4: S715-S722.

14. Gadina M, Bertini R, Mengozzi M, Zandalasini M, Mantovani A, Ghezzi P. Protective effect of chlorpromazine on endotoxin toxicity and TNF production in glucocorticoid-sensitive and glucocorticoid-resistant models of endotoxic shock. J Exp Med 1991; 173: 1305-1310.

15. Morrison DC. Bacterial endotoxins and pathogenesis. Rev Infect Dis 1983; 5 Suppl 4: 733s-747s.

16. Beutler B, Milsark IW, Cerami AC. Passive immunization against cachectin/tumor necrosis factor protects mice from lethal effect of endotoxin. Science 1985; 229: 869-871.

17. Beutler B, Krochin N, Milsark IW, Luedke C, Cerami A. Control of cachectin (tumor necrosis factor) synthesis: mechanism of endotoxin resistance. Science 1986; 232: 977-980.

18. Beutler B, Cerami AC. The biology of cachectin/TNF - a primary mediator of the host response. Annu Rev Immunol 1989; 7: 625-655.

19. Valone FH, Epstein LB. Biphasic platelet-activating factor synthesis by human monocytes stimulated with IL-1-beta, tumor necrosis factor, or IFN-gamma. $J$ Immunol 1988; 141: 3945-3950.

20. Vogel SN Havell EA. Differential inhibition of lipopolysaccharide-induced phenomena by anti-tumor necrosis factor alpha antibody. Infect Immun 1990; 58: 2397-2400.

21. Bhakdi S, Klonisch T, Nuber P, Fischer W. Stimulation of monokine production by lipoteichoic acids. Infect Immun 1991; 59: 4614-4620.

22. Schlessinger D, Schaechter M. Bacterial toxins. In: Schaechter M, Medoff G, Eisenstein BI (eds) Mechanisms of microbial disease, 2nd edn. Baltimore, MD, Williams \& Wilkins. 1993: 162-173.

23. Waage A. Bakke O. Glucocorticoids suppress the production of tumour necrosis factor by lipopolysaccharide-stimulated human monocytes. Immunology 1988; 63: 299-302.

24 Danenberg HD, Alpert G, Lustig S, Ben-Nathan D. Dehydroepiandrosterone protects mice from endotoxin toxicity and reduces tumor necrosis factor production. Antimicrob Agents Chemother 1992; 36: 2275-2279.

25. Ben-Nathan D, Maestroni GJM, Conti A. The protective effect of melatonin in viral and bacterial infections. In: Maestroni GJM, Conti A, Reiter RJ (eds) Therapeutic potential of melatonin. Frontiers of Hormone Research, vol 23. Basel, Karger. 1997: 72-80.

26. Kruisbeek AM. Proliferative assays for $\mathrm{T}$ cell function. In: JE Coligan AM et al. (eds) Current protocols in immunology. New York, John Wiley and Sons. 1992: 3.12.1-3.12.4.

27. Zuckerman SH, Shellhaas J, Butler LD. Differential regulation of lipopolysaccharide-induced interleukin 1 and tumor necrosis factor synthesis: effects of endogenous and exogenous glucocorticoids and the role of the pituitary-adrenal axis. Eur J Immunol 1989; 19: 301-305. 
28. Hadid R, Spinedi E. Giovambattista A, Chautard T, Gaillard RC. Decreased hypothalamo-pituitary-adrenal axis response to neuroendocrine challenge under repeated endotoxemia. Neuroimmunomodulation 1996; 3: 62-68.

29. Hartung T, Sauer A, Hermann C, Brockhaus F, Wendel A Overactivation of the immune system by translocated bacteria and bacterial products. Scand J Gastroenterol 1977; 32 Suppl 222: 98-99.

30. Tilders FJH, DeRijk RH, Van Dam A-M, Vincent VAM, Schotanus K, Persoons JHA. Activation of the hypothalamuspituitary-adrenal axis by bacterial endotoxins: routes and intermediate signals. Psychoneuroendocrinology 1994; 19: $209-232$.

31. Butler LD, Layman NK, Riedl PE et al. Neuroendocrine regulation of in vivo cytokine production and effects: I. In vivo regulatory networks involving the neuroendocrine system, interleukin-1 and tumor necrosis factor-alpha. $J$ Neuroimmunol 1989; 24: 143-153.

32. Zuckerman SH, Bendele AM. Regulation of serum tumor necrosis factor in glucocorticoid-sensitive and -resistant rodent endotoxin shock models. Infect Immun 1989; 57: 3009-3013.

33. Lázár G, Duda E, Lázár G. Effect of RU 38486 on TNF production and toxicity. FEBS Lett 1992; 17: 137-140.

34. Engelberg I, Von Asmuth EJU, Van der Linden CJ, Buurman WA. The interrelation between TNF, IL-6 and PAF secretion induced by LPS in an in vivo and in vitro murine model. Lymphokine and Cytokine Research 1991; 10: 127-133.

35. Gifford GA, Lohmann-Matthes ML. Gamma interferon priming of mouse and human macrophages for induction of tumor necrosis factor production by bacterial lipopolysaccharide. $J$ Natl Cancer Inst 1987; 78: 121-124.

36. Lehmann V, Freudenberg MA, Galanos C. Lethal toxicity of lipopolysaccharide and tumour necrosis factor in normal and D-galactosamine-treated mice. $J$ Exp Med 1987; 165: $657-663$.

37. Waage A, Espevik T. Interleukin 1 potentiates the lethal effect of tumor necrosis factor $\alpha$ /cachectin in mice. $J$ Exp Med 1988; 167: 1987-1992.

38. Padgett DA, Loria RM. Endocrine regulation of murine macrophage function: effects of dehydroepiandrosterone, androstenediol, and androstenetriol. $J$ Neuroimmunol 1988; 84: 61-68.

39. Schurr MJ, Fabian TC, Croce MA, Varnavas LE, Proctor KG. Dehydroepiandrosterone, and endogenous immune modulator, after traumatic shock. Shock 1997; 7: 55-59.

40. Dobbs CM, Feng N, Beck FM, Sheridan JF. Neuroendocrine regulation of cytokine production during experimental influenza viral infection. Effects of restrain stress-induced elevation of endogenous corticosterone. $J$ Immunol 1996; 157: $1870-1877$. 